\title{
Laser-Induced Spectral-Selective Autofluorescent Microscopy as a Prospective Method of Research in Biomedicine
}

\author{
Nataliia Kozan $\mathbb{D}^{1}$, Ivan Savka $\mathbb{D D}^{2^{*}}$, Viktor Kryvetskyi ${ }^{3}$, Igor Oliynyk ${ }^{4}$
}

\begin{abstract}
In modern medical diagnostics, optical methods of studying living tissues have become widespread and are collectively called "optical biopsy". One such method is autofluorescence microscopy, which provides additional information about the structural and functional features of the sample. In this paper, an analysis of existing data was performed on the properties of autofluorescence of cells and tissues to evaluate the available instrumental systems and methods for monitoring autofluorescence and the potential for its application in the biomedical field. Over the past few years, advanced optical-electronic methods have become available to detect various pathological conditions of tissues and environments of the human body by evaluating signals emitted by endogenous fluorophores. Because these molecules are often involved in basic biological processes, they are important parameters for checking the condition of cells and tissues. In our opinion, analytical methods based on autofluorescence monitoring have great potential in both research and diagnosis, and interest in the use of these new analytical tools is constantly growing. Methods based on autofluorescence can give more information about the object under study with relatively lower costs and less diagnostic error.
\end{abstract}

\section{Keywords}

Autofluorescence Microscopy; Biomedicine; Visualization; Fluorophores

${ }^{1}$ Department of Forensic Medicine and Medical Law, Ivano-Frankivsk National Medical University, Ukraine

2 Department of Forensic Medicine and Medical Law, HSEE of Ukraine «Bukovinian State Medical University $»$, Ukraine

${ }^{3}$ Department of Human Anatomy named after M.G. Turkevich, HSEE of Ukraine «Bukovinian State Medical University $»$, Ukraine

${ }^{4}$ Department of Pathological Anatomy, HSEE of Ukraine «Bukovinian State Medical University», Ukraine

*Corresponding author: sudmed@bsmu.edu.ua

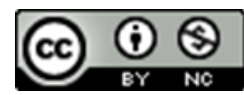

Copyright @Nataliia Kozan, Ivan Savka, Viktor Kryvetskyi, Igor Oliynyk, 2020

\section{Background}

In modern medical diagnostics, optical methods of tissue examination, called "optical biopsy", are widespread. Optical biopsy uses optical spectroscopy - absorption, fluorescence, spectroscopy of combinatorial light scattering, and methods of medical optical imaging - optical coherence tomography, confocal laser endomicroscopy [1-10]. Since the last century, technological advances in microscopy and spectrophotometry have drawn the attention of the scientific community to the fluorescence of biological tissues $[7,8,10]$. In our opinion, this area of research is promising and in the coming years there will be continuous progress in the development of new devices for detecting fluorescence and interpretation of the data, as well as finding endogenous fluorophores for use as internal biomarkers.
In this article, we want to consider the phenomenon of fluorescence, which consists in the short-term absorption of a quantum of light by a fluorophore with the subsequent rapid emission of another quantum, which has properties different from the original $[4,11]$. This phenomenon has found wide application and has become a useful tool in a large number of different biomedical studies. Many areas of biophysics, molecular and cell biology, and medicine have emerged and are developing due to the introduction of new methods based on fluorescence [12]. Fluorescence microscopy in many cases is an ideal highly sensitive technique for the study of any biological samples, because it allows you to selectively and specifically detect molecules in small concentrations $[4,7-$ $10]$.

The aim of the work was to analyze the existing data on 
the autofluorescence properties of cells and tissues, to evaluate the available instrumental systems and methods for monitoring autofluorescence and the potential for its application in the biomedical field.

\section{Discussion}

Fluorescent methods of optical biopsy can be divided into two classes: those based on the detection of fluorescence of endogenous fluorophores - autofluorescence (AF); and methods for the use of various fluorescent compounds - fluorescent labels and probes introduced into the tissue to visualize the studied processes [11].

The term "autofluorescence" is used to distinguish the internal fluorescence of cells and tissues from the fluorescence obtained by processing samples with exogenous fluorescent markers that bind cell and tissue structures [4, 13]. It should also be noted that the direct study of AF molecules opens up some new possibilities and benefits. Until recently, in fluorescence microscopy, background fluorescence of endogenous fluorophores was considered an undesirable property of the tissue, the manifestation of which had to be avoided or corrected [11]. However, the release of fluorescence by endogenous fluorophores allows their direct study through epifluorescence or confocal microscopy [12]. One of the main advantages of using AF for research purposes is that it does not require any pre-staining or sample preparation, and biological tissues or even whole living organisms can be studied with less error in the results obtained due to the introduced chemicals [13].

When excited by radiation of appropriate wavelength, some cellular and tissue components behave like endogenous fluorophores: they go into an excited state and then break down into a ground state with a loss of energy, part of which is the radiation of fluorescence [11]. It is known that the fluorescence intensity is proportional to the intensity of the incident light [13]. To separate the fluorescence from the incident light, optical filters are used, which transmit light only with a certain wavelength.

Biological tissues of human organs contain a large number of various natural biochemical fluorophores. The most common are flavins, proteins, porphyrins [4, 5, 8, 12]. Each group of fluorophores has individual absorption and radiation spectra according to the distributions of the intensity and wavelengths $[8,11,13,14]$.

In the ultraviolet part of the spectrum of electromagnetic radiation fluorescing:

1. extracellular proteins: collagen (structural protein of connective tissue and the most common protein), elastin;

2. aromatic amino acids of intracellular proteins - tryptophan, tyrosine, phenylalanine.

AF of biological tissues in the red zone of the electromagnetic spectrum is characterized by lower intensity compared to ultraviolet and shortwave visible zone. It was found that this phenomenon is associated mainly with endogenous porphyrins [5]. Much more biochemical substances are emitted (luminescent) in the blue and yellow-green regions of the spectrum: reduced pyridine nucleotides (NAD-H, NADF-H), oxidized flavoproteins (FMN, FAD), vitamins, metabolic products, including pyridoxal, folic acid, its derivatives, etc [5, 10].

When pyridine nucleotides are converted to the oxidized state, and flavoproteins to the reduced state, they lose the absorption band and the ability of electromagnetic luminescence. This fact is of diagnostic value, as biological tissue with necrotic changes is characterized by a lower $\mathrm{pH}$ level and imbalance between the content of oxidized and reduced forms of NAD, which is manifested by a decrease in the overall intensity of electromagnetic radiation [8].

The rigid relationship of many endogenous fluorophores with the morphofunctional properties of living systems, which affect the characteristics of AF emissions, provides an extremely powerful resource for direct monitoring of biological tissues [8].

Many authors, working with different cell populations, have reported that the AF pattern reflects the organization of intracellular structures, and have observed a correlation between AF and cellular energy metabolism [1, 4, 13]. These data correspond to the presence among the main endogenous fluorophores of structural proteins and molecules involved in cellular metabolism, such as pyridine and flavin nucleotides, which are considered markers of intracellular redox state. Thus, AF monitoring and analysis provides important information about cell morphology and function [8, 11].

Many studies have been conducted on the use of AF-based methods to distinguish pathological from physiological conditions in cells and tissues. A large number of methods for studying typical pathological processes based on the obtained results of AF analysis have been proposed [6-10, 15-26]. However, despite the accumulated extensive experimental experience, this method has not yet become widespread in medical diagnostic practice, as it is necessary to address the issue of standardization of research methods.

As mentioned above, in modern medical diagnostics, in situ optical methods of examination of living tissues, united by the name "optical biopsy", have become widespread. The use of optical biopsy, in contrast to conventional biopsy, involves the possibility of examining the tissue without the use of any means of fixation of the sample (for example, in the case of histological study). For research, one or another form of optical measurements is used in real time, when performing minimally invasive procedures to establish a correct diagnosis $[12,15,16,21,22]$.

The main advantage of using optical biopsy, compared to other methods of in vivo examination of organs and tissues, is the high speed of analysis. Most often, the result can be obtained in real time. A unique feature of optical biopsy, in comparison with other means of medical imaging, is the possibility of direct study of metabolic transformations in cells of biological tissues [12]. 
Currently, significant experimental material on the use of laser-induced AF spectroscopy has been accumulated for diagnostic purposes during surgery, in embryology, gastroenterology, oncology, gynecology, ophthalmology, neurology, cardiac surgery, various prototypes of installations for clinical use have been developed, a large number of methods of studying typical pathological processes (ischemia, inflammation, neoplasia, degenerative changes) are offered $[6,8-10,15-22]$.

The results of laser-induced fluorescence spectroscopy in experimental pancreatitis are presented and the possibility of using fluorescent imaging and spectroscopy of pancreatic tissue as an intraoperative rapid method in the diagnosis of pancreatic necrosis has been discussed [22]. The use of such methods makes it possible in real time to simultaneously characterize the condition of the tissue and make a diagnosis. Such systems and methods can be used to perform a biopsy during surgery.

Many scientific studies are devoted to fluorescent surgery - a field of medicine that has developed rapidly over the past decade and is widely used in surgical oncology [24]. Intraoperative imaging technologies provide information that distinguishes tumor tissues from normal ones in real time during surgery. Many of the known fluorescent indicators target the unique molecular or cellular features of tumors, which makes it possible to detect pathologically altered areas with high accuracy to perform the safest resection [24, 25].

Scientists in their research indicate that AF analysis can be successfully used to distinguish secondary lymphadenopathy from tumors of the gastrointestinal tract and normal lymph nodes $[8,15,16,18,23]$. AF spectra show that normal and metastatic areas of lymph nodes are characterized by different energy emissions. The main differences in the spectra of metastatic samples can be explained in terms of changes in the relative concentration and distribution of endogenous fluorophores. It is known that the concentration of oxidized flavins and nicotinamide adenine dinucleotide (phosphate), as well as the balance between free and bound forms of nicotinamide adenine dinucleotide phosphate) change in neoplastic cells due to changes in cell energy metabolism [23]. In order to assist in decision-making during surgery, software is currently being developed that can automatically analyze tissue by scanning all samples. It should also be noted that AF analysis is easy to perform directly on the sample in the native state (no fixation or staining is required).

Also extremely promising is the development of portable autofluorescent diagnostic methods. The team of scientists demonstrated the design of a compact and economical mobile microscope for probing a small number of fluorescent dye molecules in the visible part of the spectrum using a highly autofluorescent phantom that mimics human skin [26]. This approach may be useful for the development of fluorescence sensors that can be read subcutaneously using wearable microscopes, for continuous monitoring at home or at care points.

We also want to note the publications devoted to the diagnosis of pathological changes in the blood by autofluorescent methods. It is known that in plasma and blood serum there are a number of deviations from the norm in such pathological conditions as malignant neoplasms, diseases of the liver, joints, etc [7, 17]. A relationship was found between the magnitude of tryptophan fluorescence intensity in blood serum in surgical patients with local and generalized purulent infection. There was a correlation between the increase in tryptophan fluorescence in the protein-free fraction of homogenates of a number of organs with the increase in tryptophan fluorescence in the protein-free fraction of serum with generalized purulent infection [7].

The team of authors noted the effectiveness of the method of laser autofluorescence microscopy of synovial fluid films for the differentiation of septic and aseptic lesions of the joints during arthroplasty. The use of this technique can allow intraoperative resolution of the scope of surgery [21].

A number of works are devoted to the possibilities of using AF methods for the diagnosis of ischemic lesions of internal organs, in particular the brain, heart, blood vessels [8$10,19]$. The method of laser induced fluorescence allows to set the left shift of NAD+/NADH ratio which is one of key processes in ischemia. The method of laser induced fluorescence is sensitive to changes in this ratio. It allows for real time registration of myocardial viability and can be promising for the diagnosis of myocardial changes in situ [19].

We'd like to note that AF methods are widely used in forensic examination [27-31]. The developed optical technology of multidimensional laser-induced AF polarimetry of preparations of biological tissues and fluids of human organs, which is based on experimental vector-parametric and Mueller-matrix mapping of autofluorescence processes of molecular biological crystallites, which corresponds to the world level of biophysical diagnostic technologies. Scientists in the field of forensic medicine searched for and developed laser polarization criteria for diagnosing lifelong and postmortem changes in biological tissues and environments of the human body to establish the time since death in its different types, time of injuries formation, diagnosis of acute ischemia and degree of acute blood loss [28-31].

According to the authors, the time range for determining the time since death is due to the peculiarities of postmortem changes in laser auto-fluorescent images of biological tissues in the range from 1-140 hours with an accuracy of 1.5 hours. However, subsequent studies by the authors provide increased research accuracy. Thus Garazdyuk M.S. and authors propose a method of autofluorescence analysis of microscopic images of cerebrospinal fluid films in the temporal monitoring of postmortem changes in the optical manifestations of polycrystalline networks in order to determine the time since death. Scientists have established an interval of 24 hours with an accuracy of determining the age of death of 25 minutes [28]. Also promising in this direction is the authors' study on autofluorescent assessment of the vitreous body [24]. After conducting spectral-selective laser autofluorescence microscopy of the amorphous component of the vitreous body layers, sci- 
entists have expanded the range of sensitivity of the method of determining the time since death to 36 hours and increased the accuracy of determination to 20 minutes [30].

Vanchulyak O.Y. and co-authors based on a generalized model of optical anisotropy of myocardial tissue experimentally tested the method of autofluorescence of laser polarimetry. Within the framework of the applied approach the interrelations between the statistical moments characterizing maps of polarizations of laser autofluorescent images of histological sections of a myocardium, and features of its pathological states are revealed. This technique allows not only to diagnose acute coronary insufficiency but also to differentiate it from other pathological conditions [29].

Also interesting is the work of a team of scientists devoted to the study of the possibility of using the method of spectralselective fluorescence microscopy of histological sections of human internal organs to determine the degree of blood loss [31]. The most accurate results of establishing the degree of blood loss up to $2500 \mathrm{ml}$ provides a study of this method of biological preparations of the spleen.

In our opinion, the results of the application of AF techniques significantly expand the existing ideas about the structure and dynamics of pathological conditions of human biological tissues and indicate the prospects for further research in this area.

\section{Conclusions}

Thus, from the point of view of theory, methods based on autofluorescence can give more information about the object under study with relatively lower costs and less diagnostic error. In our opinion, it is promising to conduct further research in this area to address the following issues:

- detection of the relationship between the emission properties and the microstructure of cells/tissues, both normal and pathologically altered;

- optimization of diagnostic sensitivity and/or specificity by using specific wavelengths of excitation/radiation for different types of biological tissues or different genesis of diseases and testing the effectiveness of new methods in comparison with standard methods, which requires large-scale clinical trials.

\section{Conflict of Interest}

The authors declare that no conflicts exist.

\section{Financial Disclosure}

The authors declared no financial support.

\section{References}

[1] Albrecht C. Joseph R. Lakowicz: Principles of fluorescence spectroscopy, 3rd Edition. Analytical and Bioanalytical Chemistry [Internet]. 2008 Jan 16;390(5):1223-1224. Available from: https://doi.org/10.1007/s00216-007-1822-x
[2] Stockert JC, Blazquez-Castro A. Fluorescence Microscopy in Life Sciences [Internet]. Bentham Science Publishers; 2017. Available from: http://doi.org/10.2174/97816810851801170101

[3] Ghosh A, Karedla N, Thiele JC, Gregor I, Enderlein J. Fluorescence lifetime correlation spectroscopy: Basics and applications. Methods [Internet]. 2018 May;140-141:32-39. Available from: https://doi.org/10.1016/j.ymeth.2018.02.009

[4] Valeur B. Molecular Fluorescence. digital Encyclopedia of Applied Physics [Internet]. 2009 Dec 15:477-531. Available from: https://doi.org/10.1002/3527600434.eap684

[5] Feofanov AV. Spektral'naja lazernaja skanirujushhaja konfokal'naja mikroskopija $\mathrm{v}$ biologicheskih issledovanijah. Uspehi biologicheskoj himii. 2007;47:371410. Available from: https://www.fbras.ru/wpcontent/uploads/2017/10/Feofanov.pdf

[6] Croce A, Bottiroli G, Santin G, Pacchiana G, Vezzoni P, Di Pasquale E. Autofluorescence and metabolic signatures in a pig model of differentiation based on induced pluripotent cells and embryonic bodies. microscop [Internet]. 2014Sep.30 ;21(1):52-59. Available from: https://www.pagepressjournals.org/

[7] Ivanova SV, Kirpichenok LN. Ispol'zovanie fluorescentnih metodov $\mathrm{v}$ medicine. Medicinskie novosti. 2008;12:56-61.

[8] Salmin V. UF lazer-inducirovannaja autofluorescentnaja spektroskopija dlja medicinskoj diagnostiki. Saratov State University; 2012.

[9] Kuznecova A. Issledovanie autofluorescencii biotkani pri pomoshhi chislennogo modelirovanija metodom MonteKarlo. In: Sbornik trudov IV Vserossijskogo kongressa molodyh uchenih. Sankt-Peterburg; 2015. p. 230-232.

[10] Babkina AS. Laser-Induced Fluorescence Spectroscopy in the Diagnosis of Tissue Hypoxia (Review). General Reanimatology [Internet]. 2019 Dec 24;15(6):50-61. Available from: https://doi.org/10.15360/1813-9779-2019-650-61

[11] Monici M. Cell and tissue autofluorescence research and diagnostic applications. Biotechnology Annual Review [Internet]. 2005;11:227-256. Available from: https://doi.org/10.1016/S1387-2656(05)11007-2

[12] Turchin IV. Methods of biomedical optical imaging: from subcellular structures to tissues and organs. Uspekhi Fizicheskih Nauk [Internet]. 2016;186(5):550-567. Available from: https://doi.org/10.3367/UFNr.2015.12.037734 
[13] Kraevoj S, Koltovoj N. Fluorescentnye metody v medicine. Kniga 11. Moskva; 2014. 228 p.

[14] Makarov MS. Fljuorescencija v issledovanii kletok: puti i vozmozhnosti. Molekuljarnaja medicina. 2013;(4):10-14.

[15] Tajiri H. Autofluorescence endoscopy for the gastrointestinal tract. Proceedings of the Japan Academy, Series B [Internet]. 2007;83(8):248-255. Available from: https://doi.org/10.2183/pjab.83.248

[16] Deal J, Mayes S, Browning C, Hill S, Rider P, Boudreaux $\mathrm{C}$, et al. Identifying molecular contributors to autofluorescence of neoplastic and normal colon sections using excitation-scanning hyperspectral imaging. Journal of Biomedical Optics [Internet]. 2018 Dec 27;24(02):1. Available from: https://doi.org/10.1117/1.JBO.24.2.021207

[17] Tomka Y, Gorsky M, Soltys I, Talakh M, Drin Y, Yatsko $\mathrm{O}$, et al. Spectral and selective laser autofluorescent microscopy of blood films. Novel Optical Systems, Methods, and Applications XXII [Internet]. 2019 Sep 9:41. Available from: https://doi.org/10.1117/12.2529321

[18] Buchwalow I, Atiakshin D, Samoilova V, Boecker W, Tiemann M. Identification of autofluorescent cells in human angioimmunoblastic T-cell lymphoma. Histochemistry and Cell Biology [Internet]. 2017 Dec 2;149(2):169-177. Available from: https://doi.org/10.1007/s00418-0171624-y

[19] Sergeeva EA. Diagnostika miokarda in situ: vozmozhnosti opticheskoj biopsii. Sibirskij medicinskij zhurnal. 2016;31(2):114-116.

[20] Morgan ML, Kaushik DK, Stys PK, Caprariello AV. Autofluorescence spectroscopy as a proxy for chronic white matter pathology. Multiple Sclerosis Journal [Internet]. 2020 Aug 11:135245852094822. Available from: https://doi.org/10.1177/1352458520948221

[21] Protsiuk V, Vasiuk V, Vasilchysin Y, Kvasnyuk D, Ushenko A, Shaplavskiy M, et al. Differential diagnosis of aseptic and septic loosening of an artificial hip joint endoprosthesis cup using spectral-selective laser autofluorescence microscopy. In: Angelsky O V., editor. Fourteenth International Conference on Correlation Optics [Internet]. SPIE; 2020. p. 76. Available from: https://doi.org/10.1117/12.2553990

[22] Arutjunjan AV, Cherdancev DV, Salmin VV, Skomoroha DP, Salmina AB. Intraoperacionnaja lazerinducirovannaja fluorescentnaja spektroskopija pri jeksperimental'nom pankreatite. Sibirskoe medicinskoe obozrenie. 2012;77(5):20-24.

[23] Pantalone D, Andreoli F, Fusi F, Basile V, Romano G, Giustozzi G, et al. Multispectral Imaging Autofluorescence Microscopy in Colonic and Gastric Cancer
Metastatic Lymph Nodes. Clinical Gastroenterology and Hepatology [Internet]. 2007 Feb;5(2):230-236. Available from: https://doi.org/10.1016/j.cgh.2006.11.013

[24] Zhang DY, Singhal S, Lee JYK. Optical Principles of Fluorescence-Guided Brain Tumor Surgery: A Practical Primer for the Neurosurgeon. Neurosurgery [Internet]. 2018 Jul 30;85(3):312-324. Available from: https://doi.org/10.1093/neuros/nyy315

[25] Chang SW, Donoho DA, Zada G. Use of optical fluorescence agents during surgery for pituitary adenomas: current state of the field. Journal of Neuro-Oncology [Internet]. 2018 Dec 6;141(3):585-593. Available from: https://doi.org/10.1007/s11060-018-03062-2

[26] Göröcs Z, Rivenson Y, Ceylan Koydemir H, Tseng D, Troy TL, Demas V, et al. Quantitative Fluorescence Sensing Through Highly Autofluorescent, Scattering, and Absorbing Media Using Mobile Microscopy. ACS Nano [Internet]. 2016 Sep 19;10(9):8989-8999. Available from: https://doi.org/10.1021/acsnano.6b05129

[27] Bachinskiy V, Boichuk T, Ushenko A. Laser polarimetry of biological tissues and fluids. LAP LAMBERT Academic Publishing; 2017. 204 p.

[28] Bachynskyi V, Garazdiuk M, Vanchuliak O, Bezhenar I, Garazdiuk O. Post mortem interval estimation: features of cerebrospinal fluid films autofluorescent laser polarimetry. Fol Soc Med Leg Slov. 2016;6(2):67-72.

[29] Sarkisova YuV, Harazdiuk MS, Palyvoda OH, Andriichuk AO. Cpektralno-selektyvna lazerna avtofluorestsentna mikroskopiia preparativ amorfnoi skladovoi sklopodibnoho tila oka liudyny u diahnostytsi davnosti nastannia smerti. In: Aktualni problemy morfolohii v teoretychnii ta praktychnii medytsyni. Chernivtsi: BSMU; 2019. p. 90-91.

[30] Boichuk TM, Bachinskiy VT, Vanchuliak OY, Minzer OP, Garazdiuk M, Motrich A V. Statistical and fractal analysis of autofluorescent myocardium images in posthumous diagnostics of acute coronary insufficiency. In: Mohseni H, Agahi MH, Razeghi M, editors. Biosensing and Nanomedicine VII [Internet]. 2014. Available from: https://doi.org/10.1117/12.2061280

[31] Ushenko OG, Syvokorovskaya A-V, Bachinsky VT, Vanchuliak OY, Dubolazov AV, Ushenko YO, et al. Laser Autofluorescent Microscopy of Histological Sections of Parenchymatous Biological Tissues of the Dead. In: 4th International Conference on Nanotechnologies and Biomedical Engineering [Internet]. 2019. p. 507-511. Available from: https://doi.org/10.1007/978-3-03031866-6_91 
Received: 2020-09-02

Accepted: 2020-11-10

Revised: 2020-10-23 